\title{
Metasomatic column \\ with the apobasite listvenites end-member from the Slovinky-Gelnica ore field (Gemeric Superunit, Western Carpathians) and comparison to their type localities from Ural
}

\author{
Mária Šimurková \\ Comenius University, Faculty of Natural Sciences, Department of Geochemistry; Mlynská dolina G, 84215 Bratislava, \\ Slovakia; e-mail: simurkova.maria@gmail.com
}

(C) 2015 Authors. This is an open access publication, which can be used, distributed and reproduced in any medium according to the Creative Commons CC-BY 4.0 License requiring that the original work has been properly cited.

A metasomatic column (or metasomatic zone pattern) is the complete sequence of metasomatic zones characterising an individual metasomatic facies (Zharikov et al. 2007). The genesis of this column is the result of a series of processes, in the case of basic rock protolith leading to the formation of apobasite listvenites (in the sense of Sazonov 1975). It includes three partial processes: 1) carbonatization, 2) silicification and 3) formation of mica (e.g. Plissart et al. 2009) involving the infiltration of a $\mathrm{CO}_{2}$-rich fluids and shows similarity to processes of listvenitisation (e.g. Clayton 1993). Field research in Slovinky-Gelnica ore field has revealed the presence of such a metasomatic column (cf. Ivan 1987). It comprises metabasites as the protolith, carbonatised metabasites, listvenite-type metasomatites and listvenites s.s. The metabasites have features of subvolcanic rock types (Ivan 2009), what makes them comparable with similar rocks from Ural. The petrographic study of selected samples has showed that amphibole, chlorite and albite became progressively unstable in this sequence of alterations, replaced by carbonate, silica and lastly by the muscovite minerals, sericite or fuchsite (Ivan 1987). Carbonates change their quantity as well as mineralogical composition with the development of the column in two trends of changes: towards $\mathrm{Mg}$-Fe carbonates or
$\mathrm{Mg}$-Ca carbonates. Regarding the samples from Ural, $\mathrm{Fe}$-dolomites and ankerites predominate, the metasomatic columns derived from gabbros and dolerites are essentially the same. The geochemical study of rock samples from the study area (22 whole rock analyses) as well as the comparison with similarly metasomatised rock series from Ural (56 analyses) allowed as to give more detailed characterization of the metasomatic column. The most obvious change is a clear increase of $\mathrm{K}$ with decreasing $\mathrm{Na}$ as a sign of the albite break-up and $\mathrm{K}$-rich minerals (such as muscovite) formation. The increase of LOI and $\mathrm{CO}_{2}$ indicate the process of carbonatisation. Listvenitisation is often associated with the hydrothermal ore veins formation and the rare metal mineralization with concentration of elements such as $\mathrm{Au}, \mathrm{Co}, \mathrm{Sb}, \mathrm{Cu}, \mathrm{Ni}$ (e.g. Dinel et al. 2008, Buckman \& Ashley 2010). This could be significant as regards the genesis of stratiform ore deposits within the Slovinky-Gelnica ore field.

\section{REFERENCES}

Buckman S. \& Ashley P.M., 2010. Silica-carbonate (listwanites) related gold mineralisation associated with epithermal alteration of serpentinite bodies. New England Orogen 2010, Conference Proceedings, 16-19 November 2010, University of New England, Armidale, New South Wales, Australia, 94-105. 
Clayton R., 1993. Basalt carbonatisation and its implications for antimony mineralisation in north Cornwall. Proceedings of the Ussher Society, 8, 2, 105-111.

Dinel E., Fowler A.D., Ayer J., Still A., Tylee K. \& Barr E., 2008. Lithogeochemical and Stratigraphic Controls on Gold Mineralization within the Metavolcanic Rocks of the Hoyle Pond Mine, Timmins. Economic Geology, Special Issue, 103, 6, 1341-1363.

Ivan P., 1987. Hydrotermálne-metasomatické premeny v slovinsko-gelnickom rudnom poli. [in:] Ivan P. (eds), Mineralogicko-geochemický výskum sulfidickej mineralizácie ložiska Slovinky, Technicko-ekonomický spravodaj Železnorudných baní, n. p., Spišská Nová Ves, 58-63.

Ivan P., 2009. Staropaleozoický bázický vulkanizmus Západných Karpát: geochémia a geodynamická pozícia. Acta
Geologica Universitatis Comeniae, Monografická séria, Bratislava.

Plissart G., Féménias O., Mãruntiu M., Diot H. \& Demaiffe D., 2009. Mineralogy and Geothermometry of gabbro-derived listvenites in the Tisovia-Iuti ophiolite, southwestern Romania. The Canadian Mineralogist, 47, 1, 81-105.

Sazonov V.N., 1975. Listvenitizatsiya i orudeneniye. Nauka, Moskva.

Zharikov V.A., Pertsev N.N., Rusinov V.L., Callegari E. \& Fettes D.J., 2007. Metasomatism and metasomatic rocks. Recommendations by the IUGS Subcommission on the Systematics of Metamorphic Rocks: Web version 01.02.07. [on-line:] http://www.bgs.ac.uk/scmr/docs/papers/paper_9.pdf [access: 27.02.2015]. 